\title{
Profiling students' environmental care attitudes taught using Sasak Tribe local wisdom-integrated model
}

\author{
H. Hunaepi a,1,*, Ika Nuraini Dewi b,2, S. Sumarjan a,3 \\ a Biology Education Study Program, Faculty of Mathematics and Natural Sciences Education, Universitas Pendidikan Mandalika, \\ J. Pemuda No. 59A Mataram, West Nusa Tenggara 83126, Indonesia \\ Agroecotechnology Study Program, Faculty of Agriculture, Universitas Mataram, JI. Majapahit No. 62 Mataram, West Nusa Tenggara \\ 83125 , Indonesia \\ 1 hunaepi@ikipmataram.ac.id *; 2 ikanuranidewi@ikipmataram.ac.id; ${ }^{3}$ sumarjan@gmail.com; \\ ${ }^{*}$ Corresponding author
}

\begin{tabular}{|c|c|}
\hline ARTICLE INFO & ABSTRACT \\
\hline $\begin{array}{l}\text { Article history } \\
\text { Selected paper from The } 1 \text { st } \\
\text { National Conference on Education, } \\
\text { Social Science, and Humaniora } \\
\text { (NC-ESSH), Mataram, West Nusa } \\
\text { Tenggara-Indonesia, August 24, } \\
2019 \text { (ocs.litpam.org/index.php/ } \\
\text { index). Peer-reviewed by } \\
\text { NC_ESSH Committee and Editorial } \\
\text { Board of JPBI (Jurnal Pendidikan } \\
\text { Biologi Indonesia) } \\
\text { Received October 10, } 2019 \\
\text { Revised November 01, } 2019 \\
\text { Accepted November 19, } 2019 \\
\text { Published November } 30,2019\end{array}$ & $\begin{array}{l}\text { Sasak Tribe possesses unique local wisdom which is potential to be utilized in term of } \\
\text { improving students' care attitudes toward the environment. This study aimed at profiling } \\
\text { students' evironmental attitudes who were taught using Sasak Tribe local wisdom- } \\
\text { integrated model. This descriptive research was designed with a one-shot case study. } \\
\text { The sample used in this study was } 140 \text { VII graders chosen using random sampling } \\
\text { technique. The sample comprised of } 3 \text { classes of SMPN } 2 \text { Gunung Sari and } 3 \text { classes } \\
\text { of SMPN } 3 \text { Lingsar placed in West Nusa Tenggara-Indonesia. The data analysis } \\
\text { technique used was descriptive statistics in term of central tendency. The measured } \\
\text { indicators were cognitive component (CC), affective component (AC), and conative } \\
\text { component (ConC). The results showed that the students live in suburb area tended to } \\
\text { have better environmental care attitudes, in which the mean values were } 86.66 \text { (CC), } \\
75.69 \text { (AC), and } 42.66 \text { (ConC) compared to those who live in urban area in which the } \\
\text { mean values were } 68.73 \text { (CC), } 57.07 \text { (AC), and } 30.62 \text { (ConC). Based on this findings, } \\
\text { further evaluation in several aspects should be done. }\end{array}$ \\
\hline $\begin{array}{l}\text { Keywords } \\
\text { Environmental care attitudes } \\
\text { Integrated model } \\
\text { Local wisdom } \\
\text { Sasak Tribe }\end{array}$ & $\begin{array}{l}\text { Copyright } \odot \text { 2019, Hunaepi et al } \\
\text { This is an open access article under the CC-BY-SA license }\end{array}$ \\
\hline
\end{tabular}

\section{INTRODUCTION}

Human behavior is formed through a reciprocal relationship between humans and their environment (Utina, 2012). This explains that humans and their behavior are part of the order of life which forms the ecological system. Humans interact with the environmental components and natural resources to meet their life needs. As the human acitivities development, the declining quality of the environment will be occured which is marked by the environmental damage. The loss of ecosystem functions over the past five years has been influenced by knowledge, attitudes, behavior and the community role in utilizing and managing natural 
resources which exceed boundaries. The use of natural resources that surpasses the capacity and the low quality of human resources in managing natural resources is one of underlining factors cause the environmental crises (Utina, 2012; Muhaimin, 2015). Ecosystem damage in forest areas due to illegal logging is one of clear evidences of community indifference. The environmental crisis cannot be resolved instantly, it requires serious efforts to change the mindset as considerable as the awareness of the community so that they are encouraged to actively participate in managing the environment and ecological behavior to maintain the natural balance. The integration of local wisdom into education can be promising alternative to deal with those matters.

The Sasak people have a tradition which is quite effective in managing natural resources (Widisono, 2019) as well as preserving ecosystems from destructive activities. The traditions (behavior or habits) have been developed in accordance with the Sasak people interactions with their environment. The existence of local wisdom of the Sasak Tribe contributes to prevent the occurrence of environmental crisis in the Mount Rinjani forest area. Some local wisdoms which are still maintained today include the gora rice farming system (gogo rancah) (Permadi, Asmony, Widiana, \& Hilmiati, 2018) and Bau Nyale festival (Ardi, 2019) in which called as awiq-awiq (local rules) (Dharmawibawa, 2019). The gora rice farming system is a form of local knowledge of the Sasak people in farming, from managing the agricultural land to planting to carry out the harvest. Generally, adequate water supply is one of the important factors in rice production. However, by implementing the gora rice farming system, people only require minimum amount of water. Gora rice planting is carried out in dry or rain-fed soil. As the consequences, gogo rancah rice is relatively resistant to drought stress while still having high productivity.

Bau Nyale is a local tradition of the Sasak people (Ardi, 2019). According to legend, Nyale is the incarnation of the princes of kingdom Lombok Putri Mandalika. The princess sacrificed by throwing herself in the ocean to maintain the peace in the kingdom and to become Nyale. Therefore, the tradition of catching Nyale has been raising the local people's belief that Nyale can bring prosperity. Nyale only appears once a year (Zulhadi, 2018), it is five days after the first full moon in February. Nyale appears before dawn rolling along with the waves, and will disappear from the surface of the sea along with the appearance of sunlight. The magic of Nyale for the Sasak Tribe is one form of togetherness in community. The local wisdom of the Sasak people is also seen from the way they manage and use the forest as an ecological and conservation function by making local rules (awiq-awiq). The biodiversity of endemic plants in Lombok Island was utilized by the local community as traditional medicine. There is a belief among public that some diseases which are difficult to cure by medicinal drugs come from withcraft, hence, the treatment should be traditional medicine. Prohibition/protection and maintainance to prevent environmental damage trhough awiq-awiq, the natural resources exist can be properly and sustainably used for humans' live.

The local wisdom of the Sasak people has an environmental value which needs to be nurtured and developed so as not to be overwhelmed by the progress and challenges of people's lives. Clayton, S., and Myers (2009) explained that culture can be used to stimulate self-awareness in preserving nature. Hence it needs to be introduced to young generations (Wijayanto, 2012) through various fields (Astria, 2018) (Dharmawibawa, 2019) to ensure Indonesian cultures conservation. Surata and Vipriyanti (2018) concluded that teachers and students who showed positive attitudes towards the environment apparently still had limited knowledge and experience, so the local context needs to be embedded in environmental education. Culture can also potentially be used as part of environmental preservation (Marlina et al., 2015). Similarly, Ramdani and Sapriya (2017) and Suastra (2010) expressed that community culture or traditions in preserving ecosystems is one form of local wisdom. Those are community activities in a certain area to act and behave toward something which is believed to be true. Therefore, the learning process in schools should use local wisdom which containes environmental values.

Environmental care is an action or responsible effort taken to prevent environmental damage as well as repairing natural damage occurred (Zubaedi, 2011). The attitude of caring for the environment becomes an important value to be developed within the framework of Character Building. Ichsan, Sigit, Miarsyah, Azrai, and Heryanti (2019) stated that the environmental carness behavior is important to be owned by every individual as it will keep the environment in a good condition; thus, it can be passed for next generations. As the consequences, humans are habituated to pay their attention to the environmental sustainability so that the environmental functions can optimally support sustainable life. The development of environmental care is embeded in the Curriculum 2013 which carries a balance between knowledge, skills, and attitudes (Aninda \& Suryadarma, 2017). By improving the environmental careness, students will be encouraged to pay their 
respect to their environment and consciously preserve the environment which, in turn, will have implications for students' caring attitude towards nature.

The alternative solution, which is believed to use to develop students' environmental care attitudes, is using an innovative learning model called local wisdom integration (LWI) learning model (Dewi et al., 2019). The LWI learning model is an innovation of the Problem Based Learning (PBL) model which has been proven to be effective in improving students' high-level thinking skills (Kemenritekdikti, 2005). However, the application of PBL in real class on environmental material tends to contain concepts and problem solving based on students' assumptions. Teachers tend to ignore the steps to make alternative solutions in the problem solving process (Koutsoukos et al., 2015). By seeing the potential of the local wisdom of the Sasak people as stated above, integrating the local wisdom value becomes an important part in forming the nation's cultural wealth and building an the environmental caring attitude. The LWI learning model is designed to fulfill the gap of the unavailability of a learning model which connects learning material and culture through exploring students' original views of culture which then translating them into scientific knowledge. The LWI learning model adds a certain syntax of learning which is not present yet in the PBL model by integrating community culture through the process of enculturation, assimilation, and acculturation of local wisdom.

The encluturation process is manifested by carrying out an inventory of science content which is in harmony with the local wisdom owned by students or applied in the community. Meanwhile, an assimilation process was done by students through a scientific content inventory which is in line with the local wisdom possessed by them or implemented in a society. The students also conduct study about scientific cotents which are not in accordance with their point of view to be replaced them with the daily scientific viewpoint. The acculturation process between science content and local wisdom can be held by inventorying science content with the utility value which is suitable with the society interests at the moment as well as utilizing them to replace the improper opinions or adding new ides based on the local wisdom. Local Wisdom-Integrated (LWI) learning model is oriented to the utilization of local wisdom values to manage and utilize the natural resources (Dewi et al., 2019). Through the LWI learning implementation, the environmental careness attitude is trained to the students by giving them opportunities in problem identifications, solving problems, and formulating solutions for environmental problems. The integration of local wisdom in learning model is a novelty which provides opportunity for students to directly interact with local culture and dig science contained on the culture.

However, as the high number of local wisdoms, as the consequences of high diversities of tibes and cultures, possessed by Indonesia which are not utilized yet, mainly in educational field. Yet, they have the high potentials to be integrated in learning model which is directed to develop students' environmental careness attitude. Thus, it is expected that the environmental careness attitude will be cultivated among students, thus, the students are able to maintain, restore and prevent the environment from destruction. Therefore, it is important to conduct a research about the implementation of LWI learning model in Natural Science learning material to develop environmental careness attitude.

This research aimed at profiling students' evironmental attitudes who were taught using Sasak Tribe local wisdom-integrated model. This will contribute to give an inspiration for teachers to create an innovation in insightful learning of living environment which is still unoptimal. In addition, the LWI learning implementation will provide a good opportunity in utilizing the all local potentials optimally as well as introduce Indonesian local wisdoms to the wider communities, particularly in education field.

\section{METHOD}

This pre-experimental research design was one-shot case study design (Fraenkel, Wallen, \& Hyun, 2012) in which the sampling selection technique used was random. The sample consisted of $140 \mathrm{VII}$ graders of the academic year 2017/2018. There were three classes of SMPN Lingsar students (i.e. class 7C, 7D, and 7E) and three classes of SMPN 2 Gunung Sari (i.e. class 7A, 7B, and 7C). The both junior high schools placed in West Lombok Regency were chosen based on their location. SMPN 3 Lingsar is located in urban area, while SMPN 2 Gunung Sari was placed in rural area. The school placed in urban area has experienced quite rapid development progress, thus, the influence of modernization has appeared among the society. As the migrants number increased, the heterogeneous society occured. While the school placed in urban area has different socio-cultural environment of students. The peripheral area has experienced global cultural influences, but 
does not completely abandon local culture. Some communities in the periphery are still strongly stick with their local customs.

The instruments used in this study were the scale of environmental care attitude in which the indicators were cognitive component (CC), affective component (AC), and conative component (ConC) (Ham, Mrčela, \& Horvat, 2016). The instruments have met the criteria of content and construct validity (Ika Nurani Dewi, Ibrahim, \& Poedtjiastoeti, 2017). The environmental care attitude score was given using rating scale. Students who showed a careness attitude of the environment which meet the indicators were given 3 (always), 2 (rare), and 1 (never). The data obtained were then analyzed using descriptive statistic in term of central tendency and coversion into category. The score conversion was based on Table 1.

Table 1. Score conversion of students' environmental careness attitude

\begin{tabular}{cc}
\hline Score interval & Category \\
\hline $86-100$ & Very good \\
$71-85$ & Good \\
$56-70$ & Enough \\
$40-55$ & Poor \\
$0-39$ & Very Poor \\
\hline
\end{tabular}

Source: Suhirman and Yusuf (2019)

\section{RESULTS AND DISCUSSION}

This research was conducted to implement the LWI learning model by orienting the goals of developing insight, careness attitude, and environmental culturing. The LWI learning model is expected to help students in developing and utilizing moral values, ideas, positive point of view of community, capable, careful, and full of wisdom. The learning which utilizes a relevant local wisdom which refers to the phylosphy of curriculum 2013 development, in term of education based on nation-culture-based learning to build nation live in the present and the future. Culture-based learning is still limited in inserting local wisdom forms or values into some relevant basic competencies.

The developed LWI learning model was supported with the social constructivist theory view which reviews several components so that learning process runs in proper way in terms of Zone of Proximal Development (ZPD), scaffolding, and cognitive apprenticeship (Santrock, 2011). Several supporting theories are about cognitive learning which covers ARCS Keller about information processing theory (Slavin, 2008), Bruner discovery theory, meaningful learning theory of Ausubel, and Piaget's intellectual development theory (Moreno, 2010). The syntax of the developed LWI learning model is the combination of PBL learning steps which is integrated with local wisdom. As the result, there are five of LWI learning syntaxes, namely, 1) problem indentification through local wisdom enculturation, 2) solving problem activities, 3) discoveries reconstruction through local wisdom assimilation, 4) communicating solving problem resulted scientifictly, 5) evaluation process through the local wisdom acculturation (Ika Nurani Dewi, Poedjiastoeti, \& Prahani, 2017).

The local wisdom integration in learning can awaken social system in tolerance and democratic sircumtances which encourages students to be active in discussion session in the class. This social system emphasizes the knowledge construction conducted actively by each student which will be stronger as the activities are done collaboratively. Creating collaborative group gives positive effects toward learning achievement (Barkley, C., Barkley, E. F., Cross, K. P., \& Major, 2005) in which one of them is forming environmental careness attitude. In the LWI learning model, teachers play as a facilitator who provides learning resources, encourages students to develop environmental careness attitude and offers assistances for students to construct their knowledge. Furthermore, teachers should give feed back for students' learning achievement. A conducive circumtances enable students to improve their ability in delivering information effectively as well as to advance their learning outcomes (Ajayi \& Ekundayo, 2011; Liu, Lin, Jian, \& Liou, 2012).

LWI learning model integrates local wisdom into science through enculturation, assimilation, and acculturation processes. Enculturation is a process of learning cultural values experienced by individuals in their life. Students learn to synchronize the science contents gained in school based on their own point of view through encultiration. This process is conducted through science cintents inventory which in line with the local wisdom possessed by students and applied in society. Thus, thinking skill about society cultural can dominate the students' attitude in term of their environmental awareness. Meanwhile, assimilation is an exchange process of cultural elements to decrease the differences among society groups. This process was adopted to 
integrate local wisdom to science. Students learn about science contents as well as compare them to their own viewpoint. This will enable them to condsider whether they will use their point of view or replace it with the one which suit scientific view in daily life through assimilation. Hence, their empathy towards environment are also developed along with the processes they experienced.

Aculturation is a social process arose as the consequences of interaction between the elements of new culture and certain community with their own culture. The elements of new culture, slowly but sure, will be received by the community without removing the original culture of the community. The acuturation process can be conducted by invetoring science contents whish have utility values needed by students and society. These contents will be used to replace old ideas which inappropriate as well as add new aideas based on local community. Aculturation process occurs in local wisdom values, particularly those which can increase human life quality to anticipate unexpected effect.

The LWI learning model implementation in the two schools chosen (i.e. SMPN 3 Lingsar and SMPN 2 Gunung Sari) resulted the mean values of students' achievements as served in Tabel 2. The measurement was done in three indicators namely, cognitive component, affective component, and conative component.

Table 2. The achievement of students' environmental careness attitude of SMPN 3 Lingsar and SMPN Gunung Sari

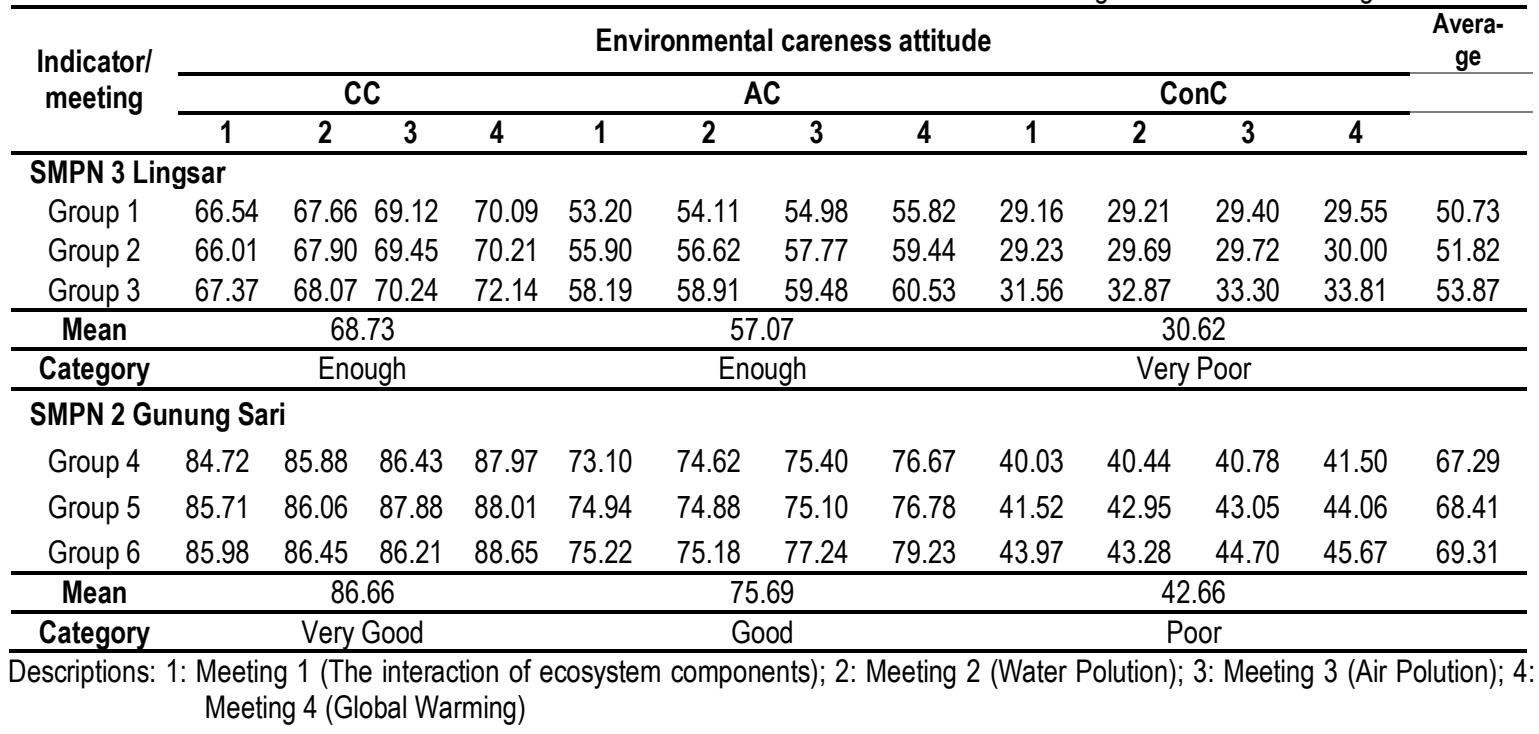

Table 2 descriptively shows the increase of students' environmental careness attitude from meeting to meeting (from the first to the fourth). This rising pattern witnessed by the two schools even though SMPN 2 Gunung Sari tended to be higher compared to SMPN 3 Lingsar in the three components measured. This fact occurred because of the obstacles faced during the implementation of LWI learning model in SMPN 3 Lingsar such as: 1) some students needed special treatment from teacher i.e. teacher must give extra enplanation for the students every meeting; 2 ) some students felt more comfortable if the were grouped witn them who have the same cognitive level. In the case of discordant condition, they tended to work themselves without any cooperation activity, thus, no interaction among group members; 3 ) the number of students was more than 20 which became hinder for teacher in optimizing class management which effected the students passiveness, unfocus, and unconditioned class.

To be more detail, of the three components measured, students' cognitive was the highest score gained by students compare to the other components. The mean value achieved by SMPN 2 Gunung Sari (86.66) was better compare to SMPN 3 Lingsar (68.73). The high cognitive achievement means that students obtained the skills in memorizing, comprehending, applying, analyzing, evaluating, and creating (Anderson \& Krathwohl, 2001) which, in turn, will influence their behavior (Ham et al., 2016). Yet it was not known the level of the cognitive enacted as, in fact, the students faced difficulties in analyzing garbage types whwther it is organic or anorganic.

The high students score is an evidence that LWI learning syntax has led the students gained their learning goal. One of the LWI learning syntax was the video of farm ecosystem phenomena served by teacher to give the students to identify problems. Hence students were driven to think and compare the phenomena they found with the padi gora farming system implemented by the local community. It was expected that students concluded that they can maintain their culture (padi gora farming system) to conserve the balance of 
abiotic and biotic components in nature. Moreover, the students were also educated to be habituated with the pro environmental attitude by creating a routin activity circumstance in school environment such as keep the school environment clean, put their garbages into the trashes provided in school, dispose the remain practicum material into proper place. Furthermore, the efforts to facilitate students in developing their environmental careness attitude were doing spontaneous activities such as giving examples in behaving towards the environment, asking students to maintain their environment, as considerable as giving advises to whom they behave improper manner toward the environment. Careness attitude can be strengthened by giving many examples by teacher (Khanafiyah \& Yulianti, 2013), providing explisit rules about constructive and maintaining behavior (Thompson \& Barton, 1994).

As the cognitive component was enacted by students with the categories of "Enough" (68.73) for SMPN 2 Gusung Sari and "Very Good" (86.66) for SMPN 3 Lingsar, the second rank component achieved was affective component. The students' achievement for affective component was in enough (57.07) and good (75.69) categories for SMPN 3 Lingsar and SMPN 2 Gunung Sari respectively (see Table 2). It proves that, practically, implementing cognitive skill, in term of knowledge about how to behave toward environment, into students' daily life is now simple thing. Most of students has independently done their task to clean their classroom every day without any force. But, somehow, there were minority who still need to be reminded to do their task properly. Similarly, albeit that, mostly, school's environment were clean, but, there also some parts of it still required more intention, this including students' careness about sparating garbages based on its types (organic and anorganic) so that they did not want to spend their time to think about it and just throw their garbage into the trash carelessly. In accordance with their willing to caring the plants surround the school, most students do their task happily, but the minority of them were reluctant to do the plant caring as there was a gardener hired by school to do plant caring every day. Moreover, the students' affective were shown in their daily activities. They tended to remind their friends who showed ignorance attitude towards environment by using polite language, and asked them to keep their environment clean and do plant caring in their school. Most of them also have high responsibility in watering plants even though there has been staff has responsibilities in caring plants.

In contrast, notwithstanding that it went better and better, the conative component was the lowest achievement enacted by students with the mean values were 30.62 for SMPN 3 Lingsar and 42.66 for SMPN 2 Gunung Sari students (see Table 2). Moreover, by considering the categorization of students' environmental careness attitude score, conative component still needs to be improved as it was included in "poor" and "very poor" categories. This did not meet the expected learning outcome. Conative includes behavioral attentions that result personal contribution in tackling the environmental problems. In fact, the students unabled to optimize their activities in recycling used materials or waste such as can and plastic or manajing harmful waste. They also have less contribution in biofertilizer production as the teacher gave them the chance to manage green waste to be proceeded into biofertilizer. Some of them said that they were not interested in that activity, even thoug some of them felt need to gain the knowledge and experiences of producing biofertilizer. Nevertheless, this activity has been recognized as an effective way to educate students to be more careful to the environment (Ardianto \& Bambang Priyono, 2014; Amini, 2015) as they learn to explore learning resources from their surrounding. They were led by teacher to do hands on activity in making biofertilizer as one of solutions to deal with environmental issues. They utilized the unused materials which can cause the abundant of waste problem. Thus, they got an idea to solve the problem directly by training students'environmental awareness about the vitality of maintaining environment.

In addition, the students were lack abilities in responding environmental issues, and giving solution. This due to the lack of creativity. Students did not have any idea in adding the utility value of used materials or waste. Generally, students' appreciation and careness towards environment have been shown. They tended to respect to the opinion, facts, and systematic arguments expressed by others. However, they were still weak in making decision about the manner they should take in facing the pro environmental act and those which bring detrimental effects to the environment. Yet, it does not mean that the learning model failed in cultivating the pro environmental behaviors on the students' personality, but normally, this learning processes need to be conducted continousely as it need very long time and gradually to be habituated in students (Wibowo, 2012). The learning process which addressed to change students' behavior should be directed to cope with environmental issues in their daily life (Khanafiyah \& Yulianti, 2013).

The conative component seemed to be weakly implemented in students' daily activities. Teacher found that most of students were rare to shut the lamp, fan, and computer after ending their learning activities; they still need to be instructed by teacher to do those things. Only little of them who were aware of saving energy 
by shutting down the electric devices and water faucet after using them. Thus, cultivating conative component within students' personality will be succeed by presenting contextual environmental issues occur among students' society and give them clear descriptions about the bad effects may they face in the future due to the ignorance attitude toward environment.

The basic concept of IL model is direct learning. Students are guided to analyze facts and phenomena, constructing rational and critical thinking framework, cultivating the curiosity, research activities, developing cognitive skill and solving problem. Thus, the better understanding about the topics discussed will be enacted as well as stimulates them to find solutions. As the longer effects of this learning, students' references in conserving environment are also widened (Aninda \& Suryadarma, 2017). The pro environmental attitudes are also habituated in the same time as the comprehension about ecological basic concepts getting better. This LWI learning model concept forms skills and active students' participation in managing life environment. This can be a proper solution for less caring students toward environment. The students are given opportunities to assess the conditions and determine the soving steps (Khanafiyah \& Yulianti, 2013; Amini, 2015).

One of the local wisdom approached to be taught to students was awiq-awiq. This is a belief among local community to not cutting trees as they are kept by certain spirits which will harm whoever cut the trees. Certainly, this traditional view must be replaced by the more scientific view. The students got the explanation that trees is resources to maintain the water supply as well as provide oxygene for human. The other local wisdom possessed by Sasak Tribe is Bau Nyale, a festival celebrated by Sasak Tribe annually. It is a tradition to Bau (=hunt) Nyale (=kind of sea worm) every year in certain full moon. This local wisdom plays an important role to maintain the sea ecosystem quality. This belief keep the local community from hunting sea worm every day which will gives detrimental effect to the sea ecosystem caused by their activities. LWI learning model has activated students to develop their horizon and strengthen their skills by utilizing their knowledge. Moreover, a good interaction between students and their environment has stimulated students' thinking. By gaining experiences from their surrounding as the subject and sources of knowledge as well as to be the guidelines to gain their learning goals. A meaningful learning can be achieved as the analysis and evaluation activities about environmental issues are conducted in students' local context which can be in form of local wisdom (Dewi, Suryadarma, Wilujeng, \& Wahyuningsih, 2017; Muhaimin, 2015). Moreover, Setiawan, Innatesari, Sabtiawan, and Sudarmin (2017) emphasized that local wisdom-based natural science learning encourages student to construct and connect between the concept and factual conditions. This in line with Keraf (2001) findings which reported that a harmonic personality with life environment can be created through local wisdom studies. This also determines students' understanding about their environment (Dwianto, Wilujeng, Prasetyo, \& Suryadarma, 2017) as their positif interaction with the nature which stimulates their empathy towards environment (Muhaimin, 2015).

To date, students understand that environmental problems have been directed to the global issues such as environmental pollution, critical land, and global warming. However, they still have an opinion that the issues mentioned are far from their environment. They need detail description about the issues which closer to them in term of more contextual for them such as the abundant of garbages, abration, drought, the decrease of environmental carrying capacity and river function. Furthermore, they do not understand the cruciality of saving energy to maintain their environment for their life. Thus, it is important to make them get environmental comprehension and the way to manage it. To realize this goal, not only their teachers but also several related parties must be involved. The school need to make a certain regulation as well as provides sufficient facilities to support the learning program (Ichsan et al., 2019), including environmental education program. Muhaimin (2015) stated that school need to cultivate ecological competition by creating habit formation, role model, and the movement to generate attitude and school culture which in line with green curriculum and green living. This, in turn, will reinforce learning activities one another whether it is the inclassroom learning or extraculicular activities.

\section{CONCLUSION}

The students' environmental careness attitude was gradually developed by impelemnting LWI learning model. This has been proven by two points: 1) the score improvements of students' attitude in each meeting, 2) the consistency of the scores among groups in each school. In addition, the material contents sourced from the social reality and local wisdom phenomena eased students to comprehend and utilize as well as manage the environmental materials wisely. Yet, students' conative were still in the lowest level compared to the other 
components. Therefore, it is recommended to direct school efforts to sharpen this component through trainings and habituations.

\section{ACKNOWLEDGMENT}

The authors would like to express the deepest gratitude to the Ministry of Research, Technology and Higher Education of Indonesia which provided funding for this research through the program of Doctoral Disertation Grant, thus, this research can be completed. A high appreciation is also addressed to IKIP Mataram, Universitas Mataram, SMPN 3 Lingsar-Mataram, West Nusa Tenggara, and SMPN 2 Gunung SariMataram, West Nusa Tenggara, which provided assistance in term of facilities to conduct this research.

\section{REFERENCES}

Ajayi, I. A., \& Ekundayo, H. T. (2011). Factors determining the effectiveness of secondary schools in Nigeria. Anthropologist. doi: https://doi.org/10.1080/09720073.2011.11891174

Amini, R. (2015). Outdoor based environmental education learning and its effect in caring attitude toward environment. Jurnal Pendidikan IPA Indonesia. doi: https://doi.org/10.15294/jpii.v4i1.3500

Anderson, L. W., \& Krathwohl, D. R. (2001). A taxonomy for learning, teaching, and assessing. (A. E. Burvikovs \& A. Martinez-Ramos, Eds.). New York: Addison Wesley Longman, Inc. Retrieved from https://www.uky.edu/ rsand1/china2018/texts/Anderson-Krathwohl - A taxonomy for learning teaching and assessing.pdf

Aninda, B. O., \& Suryadarma, I. G. P. (2017). Penerapan PBL dengan suplemen komik digital terhadap kemampuan pemecahan masalah dan sikap peduli lingkungan. JURNAL BIOEDUKATIKA, 5(2), 46-53. doi: https://doi.org/10.26555/bioedukatika.v5i2.6499

Ardi, M. B. (2019). Tradisi komunikasi budaya masyarakat Suku Sasak melalui Festival Bau Nyale (Studi etnografi komunikasi pada Masyarakat Suku Sasak Pulau Lombok Nusa Tenggara Barat). Malang. Retrieved from http://eprints.umm.ac.id/45587/

Ardianto, A. D., \& Bambang Priyono. (2014). Penerapan pembelajaran dengan praktikum pembuatan kompos terhadap karakter dan hasil belajar siswa. Unnes Journal of Biology Education, 3(3), 355-363.Retieved from https://journal.unnes.ac.id/sju/index.php/ujbe/article/view/4536

Astria, Y. (2018). Strategi pengembangan sektor pariwisata berbasis kearifan lokal di Provinsi Nusa Tenggara Barat. Universitas Muhammdiyah Malang. Retrieved from http://eprints.umm.ac.id/42032/

Barkley, E. F., Major, C. H., \& Cross, K. P. (2014). Collaborative learning techniques: A handbook for college faculty. San Francisco: Jossey-Bass. Retrieved from https://www.wiley.com/en-id/Collaborative+Lear ning+Techniques:+A+Handbook+for+College+Faculty,+2nd+Edition-p-9781118761557

Clayton, S., \& Myers, G. (2009). Psikologi konservasi. Jakarta: Pustaka Pelajar. Retrieved from https://www. tokopedia.com/socialagencybaru/psikologi-konservasi-susan-clayton-gene-merys

Dewi, I. N., Ibrahim, M., Poedjiastoeti, S., Prahani, B. K., Setiawan, D., \& Sumarjan, S. (2019). Effectiveness of local wisdom integrated (LWI) learning model to improve scientific communication skills of junior high school students in science learning. In Journal of Physics: Conference Series. IOP Publishing. doi: https://doi.org/10.1088/1742-6596/1157/2/022014

Dewi, I. P. M., Suryadarma, I. G. P., Wilujeng, I., \& Wahyuningsih, S. (2017). The effect of science learning integrated with local potential of wood carving and pottery towards the junior high school students' critical thinking skills. Jurnal Pendidikan IPA Indonesia. doi: https://doi.org/10.15294/jpii.v6i1.9598

Dewi, Ika Nurani, Poedjiastoeti, S., \& Prahani, B. K. (2017). ELSII learning model based local wisdom to improve students' problem solving skills and scientific communication. International Journal of Education and Research, 5(1), 107-118. Retrieved from https://www.ijern.com/journal/2017/January2017/09.pdf

Dharmawibawa, I. D. (2019). Kearifan masyarakat Desa Seloto dalam pengelolaan sumberdaya alam di Danau Lebo. Abdi Masyarakat, 1(1), 29-35. Retrieved from http://ejournal.mandalanursa.org/index.php/ $\mathrm{PB} /$ article/view/941

Dwianto, A., Wilujeng, I., Prasetyo, Z. K., \& Suryadarma, I. G. P. (2017). The development of science domain based learning tool which is integrated with local wisdom to improve science process skill and scientific attitude. Jurnal Pendidikan IPA Indonesia. doi: https://doi.org/10.15294/jpii.v6i1.7205 
Fraenkel, J. R., Wallen, N. E., \& Hyun, H. H. (2012). How to design and evaluate research in education (eight). New York: McGraw-Hill. Retrieved from https://www.academia.edu/3642866/How_to_Design_a nd_Evaluate_Research_in_Education

Ham, M., Mrčela, D., \& Horvat, M. (2016). Insights for measuring environmental awareness. Ekonomski Vjesnik/Econviews - Review of Contemporary Business, Entrepreneurship and Economic Issues, 29(1), 159-176. Retrieved from https://hrcak.srce.hr/ojs/index.php/ekonomski-vjesnik/article/view/3661

Ichsan, I. Z., Sigit, D. V., Miarsyah, M., Azrai, E. P., \& Heryanti, E. (2019). Students' pro-environmental behavior and environmental learning outcomes based on green consumerism. Jurnal Pendidikan Biologi Indonesia. doi: https://doi.org/10.22219/jpbi.v5i1.6447

Kemenritekdikti. Peraturan menteri riset, tekonologi, dan pendidikan tinggi nomor 44 tahun 2015 tentang standar nasional pendidikan tinggi [Regulation of the minister of research, technology and higher education number 44 of 2015 on national standards of higher education] (2005). Jakarta.

Keraf, A.S. (2010). Etika lingkungan hidup (Jakarta). Penerbit Buku Kompas. Retrieved from https://books. google.co.id/books?hl=en\&lr=\&id=gW6qGODQ2_cC\&oi=fnd\&pg=PR7\&dq=\%22Etika+lingkungan\%22+k eraf\&ots=rQ06ORP94M\&sig=GJu57GALhDTC01P0DQw4Pim3mok\&redir_esc=y\#v=onepage\&q=\%22 Etika\%20lingkungan $\% 22 \% 20$ keraf\&f=false

Khanafiyah, S., \& Yulianti, D. (2013). Model problem based instruction pada mengembangkan sikap kepedulian lingkungan. Jurnal Pendidikan Fisika Indonesia, 9(1), 35-42. Retrieved from https://journal. unnes.ac.id/nju/index.php/JPFl/article/view/2578

Koutsoukos, M., Fragoulis, I., \& Valkanos, E. (2015). Connection of environmental education with application of experiential teaching methods: A case study from Greece. International Education Studies. doi: https://doi.org/10.5539/ies.v8n4p23

Liu, E. Z. F., Lin, C. H., Jian, P. H., \& Liou, P. Y. (2012). The dynamics of motivation and learning strategy in a creativity-supporting learning environment in higher education. Turkish Online Journal of Educational Technology, 11(1), 172-180. Retrieved from http://tojet.net/articles/v11i1/11116.pdf

Marlina, R., Hardigaluh, B., \& Yokhebed, M. (2015). Pengambangan modul pengetahuan lingkungan berbasis potensi lokal untuk menumbuhkan sikap peduli lingkungan mahasiswa pendidikan biologi. Jurnal Pengajaran Matematika dan IImu Pengetahuan Alam, 20(1), 94-99. doi: https://doi.org/10.18269/jpmi pa.v20i1.569

Moreno, R. (2010). Educational psychology. New Mexico: John Wiley \& Sons Inc. Retrieved from https://www.abebooks.com/9780471789987/Educational-Psychology-Moreno-Roxana-0471789984/plp

Muhaimin, M. (2015). Implementasi model pembelajaran berbasis masalah lokal dalam mengembangkan kompetensi ekologis pada pembelajaran IPS. SOSIO DIDAKTIKA: Social Science Education Journal, 2. doi: https://doi.org/10.15408/sd.v2i1.1409

Permadi, L. A., Asmony, T., Widiana, H., \& Hilmiati, H. (2018). Identifikasi potensi Desa Wisata di Kecamatan Jerowaru, Lombok Timur. Jurnal Pariwisata Terapan, 2(1), 33. doi: https://doi.org/10.22146/jpt.35380

Ramdani, Y. A., \& Sapriya, S. (2017). Integration of local wisdom based on Naskah Amanat Galunggung in Civics learning. Masyarakat, Kebudayaan dan Politik, 30(4), 418-427. doi: https://doi.org/10.20473/mkp. V30|42017.418-427

Santrock, J. . (2011). Educational psychology. New York: McGraw Hil. Retrieved from https://www.academia. edu/34531242/John_Santrock_Educational_Psychology_5th_Edition_McGraw_Hill_Humanities_Social_ Sciences_Languages_2010

Setiawan, B., Innatesari, D. K., Sabtiawan, W. B., \& Sudarmin, S. (2017). The development of local wisdombased natural science module to improve science literation of students. Jurnal Pendidikan IPA Indonesia, 6(1), 49-54. doi: https://doi.org/10.15294/jpii.v6i1.9595

Slavin, R. E. (2008). Psikologi pendidikan: Teori dan praktik. Jakarta: Widya Ananda. doi: https://doi.org/10.23 887/jppundiksha.v43i1.1697

Suastra, I. W. (2010). Model pembelajaran sains berbasis budaya lokal untuk mengembangkan kompetensi dasar sains dan nilai kearifan lokal di SMP. Jurnal Pendidikan dan Pembelajaran, 43(2), 8-16. doi: https://doi.org/10.23887/jppundiksha.v43i1.1697

Suhirman, S., \& Yusuf, Y. (2019). The effect of problem-based learning and naturalist intelligence on students' understanding of environmental conservation. JPBI (Jurnal Pendidikan Biologi Indonesia), 5(3), 387396. doi: https://doi.org/10.22219/jpbi.v5i3.9817

Surata, S. P. K., \& Vipriyanti, N. U. (2018). The Subak cultural landscape as environmental education: Knowledge, attitudes, and experiences of Balinese teachers, student teachers, and students. Journal of 
Environmental Education. doi: https://doi.org/10.1080/00958964.2017.1406890

Thompson, S. C. G., \& Barton, M. A. (1994). Ecocentric and anthropocentric attitudes toward the environment. Journal of Environmental Psychology, 14(2), 149-157. doi: https://doi.org/10.1016/S02724944(05)80168-9

Utina, R. (2012). Kecerdasan ekologis dalam kearifan lokal masyarakat Bajo Desa Torosiaje Provinsi Gorontalo. In Prosiding Konferensi dan Seminar Nasional Pusat Studi Lingkungan Hidup Indonesia ke 21 (pp. 14-20). Mataram: PSL Universitas Mataram. Retrieved from http://repository.ung.ac.id/karya ilmiah/show/334/kecerdasan-ekologis-dalam-kearifan-lokal-masyarakat-bajo-desa-torosiaje-provinsi-go rontalo.html

Wibowo, A. (2012). Pendidikan karakter. Yogyakarta: Pustaka Belajar. Retrieved from https://www.research gate.net/publication/290440087_Pendidikan_Karakter_Strategi_Membangun_Karakter_Bangsa_Berper adaban

Widisono, A. (2019). The local wisdom on Sasak Tribe Sade Hamlet Central Lombok Regency. Local Wisdom : Jurnal IImiah Kajian Kearifan Lokal, 11(1), 42-52. doi: https://doi.org/10.26905/Iw.v1111.2711

Wijayanto, O. A. (2012). Kearifan lokal (Local wisdom) dalam praktik bisnis di Indonesia. FORUM., 40(2), 611. Retrieved from https://ejournal.undip.ac.id/index.php/forum/article/view/8201/6721

Zubaedi. (2011). Design pendidikan karakter, konsepsi dan aplikasi dalam lembaga pendidikan. Jakarta: Kencana. Retrieved from https://ebooks.gramedia.com/id/buku/desain-pendidikan-karakter-konsepsidan-aplikasinya-dalam-lembaga-pendidikan

Zulhadi, H. (2018). Penentuan tanggal Bau Nyale dalam kalender Rowot Sasak (Analisis sosial adat budaya). Ulumuna, 4(217-241), 1689-1699. Retrieved from http://ejournal.kopertais4.or.id/madura/index.php/ulu muna/article/view/3503/2579 